\title{
Revoking Besieged Memories: Scanning Modes of Memory in Alexis Wright's Carpentaria
}

\author{
Manchusha Madhusudhanan \\ Assistant Professor \\ Department of English \\ Maharaja's College \\ Ernakulam, Kerala India \\ manchusha@maharajas.ac.in
}

\begin{abstract}
The dominant history of Australia has always reflected the beauty and abundance of its aboriginal world, in dim light. An analysis of the literary canon too proves this lack of acknowledgement and understanding, of the native ways of life and identity formations. Carpentaria by Alexis Wright challenges the very notion of history as a single strand of chronologically ordered set of events. When besieged memories are evoked new traces of memory surface shedding new light on the past. It initiates a process rewriting history. Postmodern historiography today accepts the subjectivity and literariness of histories. Only a thin line exists between history and fiction. In a nation's narrative, memory is a trope that foregrounds the polyphonic voices of the nation. The imaginary town of Desperance in Carpentaria is a microcosm of the Australian society. It is here, truth and appropriations crisscross to create a true picture of the Australian society.
\end{abstract}

Keywords: Cultural Memory, Communicative Memory, Sites of memory, Bearers of Cultural Memory 


\section{Introduction}

Memories are alive and evolving. Forgetting is possible only if something has been memorised. Aboriginal memories are alive but marginalised and dominated by the foreigners who fail to comprehend its depth and relevance. Belonging to the Australian Waanyi tribe, Alexis Wright takes it upon herself to voice the silenced memories of her land. She has to her credit three well received novels; Plains of Promise (1997) Carpentaria (2006) and The Swan Book(2014). Carpentaria won her the coveted Miles Franklin award in 2007 and widened her international readership. This paper attempts to project Carpentaria as a "fiction of memory" (Neumann 334). The study of modes of memory that helps natives to revive identities and initiate a better understanding of themselves and the world around is an eye opener in many respects.

The term fictions of memory introduced by Ansgar Nunning, in the broad sense "refers to the stories that individuals or cultures tell about their past to answer the question "who am I?", or, collectively, "who are we?"” (Neumann 335). All postcolonial texts try to voice in one way or the other the atrocities, persecutions and resistance, of marginalised communities during the colonial regime. Dead ancestors and forgotten events resurface through such descriptions. Alexis Wright uses magic realism and dreamtime narration, to carve a niche for the aboriginal world she belongs to. In her works memory is "contested, multiple and negotiated" (Confino 80).

The text opens with the phrase "nation chants" (Wright, Carpentaria1), pulling the reader into a long chain of individual and group recollections. Wright is full of memories, supplied by her elders, especially her grandmother. Wright finds that these memories stand in stark contrast to the memories circulated by visuals, texts and culture around her. Wright has indirectly published her grandmother's stories through her novel Carpentaria. 
She chose stories about the kinds of ideas that would forge an anchor in her traditional country. In my lifetime, I have learnt many other stories about our family that my grandmother did not tell me. I know some of the best and the worst of our history. She chose what she wanted remembered. Perhaps intuitively, perhaps intentionally, she understood that the stories she did not want to tell could not provide a strong anchor. Indeed, they were the stories to create destructiveness. I have found the anchor she passed on has stood firm in life. It has weathered stormy patches as firmly as it has stayed steady in the calm (Wright,"Writing” 9).

In Carpentaria family, history, myth, traditions, religion etc. function as channels thorough which memory is retrieved, kept alive and passed on."Myth, religious memory, political history, trauma, family remembrance, or generational memory are different modes of referring to the past. Seen this way, history is but yet another mode of cultural memory, and historiography its specific medium" (Boer 7). Study of modes of memory helps to historicise the text taken up for study. It is an attempt to understand a text within the entire historical context it was created in.

A unique feature that makes this novel stand apart, is its use of dreamtime to reflect the mythological past of aboriginal Australia. It foregrounds the history hidden in the aboriginal psyche. Past, present and future fuse into a single strand. A dreamtime narrative includes - creation stories, life stories of ancestors, concepts of life and death, and sources of power that renews forgotten memories, leading to stronger identities. Usual manifestations of time and space are not adhered to in Wright's novel. The concepts proposed by the cultural memory paradigm, to a great extent intersects the modalities of dreamtime narrative. 


\section{Communicative Memory}

In 1920s, Maurice Halbwachs introduced the concept of Collective memory, dissociating the study of memory from of its biological constrains. "Collective memory refers to the shared pool of memories, knowledge and information of a social group that is significantly associated with the group's identity" (Halbwachs 10). He points out that apart from individual memory, there exists social memory, created and circulated by groups. These group identities play a significant role in the formation of communities, histories and nations. His books, originally written in French were translated and published in 1980's -The Collective Memory and On Collective Memory. He noted that "collective memory is essentially a reconstruction of the past in the light of the present" (Halbwachs34). He advocated that human beings possessed two types of memory one individual and the other collective. "It is in society that people normally acquire their memories. It is also in society that they recall, recognise, and localise their memories" (38). So all the activities in Desperance lead to the circulation of collective memories. These include everyday conversations, anecdotes, rituals and ceremonies etc. When Halbwachs' collective memory, is used as a lens to analyse postcolonial aboriginal novelists, the focal point is the formation of group identity through intergenerational transmissions.

\section{Cultural Memory}

In the 1970's Jan Assmann and his wife Aleida Assmann's studies on memory led to the division of collective memory into two - communicative and cultural memory. Communicative memory is very similar to collective memory. Halbwachs has shown that memory is "(a) socially mediated and (b) relates to a group" (J. Assmann 127). J. Assmann argues that collective memory which is basically oral in its manifestation, sustains itself approximately for three or four generations, after which it disintegrates. Within this limited 
time, it bases itself on informal and everyday communications between members of a group. Hence its scope is limited. Halbwachs ended his research on collective memory in the belief that once communications in the group gets crystallised or objectified, the group loses all its contemporary references and "Memoire is transformed into histoire" (128). But Cultural Memory introduced by J. Assmann does not crystallise. They mediate new meanings and are functional in the society.

The aboriginal "world is epic" ("Writing" 1) says Wright. The nation is full of stories, the land is noisy and wants to be heard. Memory is the native's tool to reconcile with who they really are.Collective memory and cultural memory are essential for identity formation and attaining selfhood. Wright justifies her all empowering hybrid narrative strategy in her essay "On Writing Carpentaria" thus:

It follows the original pattern of the great ancient sagas that defined the laws, customs and values of our culture. The oral tradition that produced these stories continued in the development of the epic stories of historical events, and combining ancient and historical stories, resounds equally as loudly in the new stories of our times (2).

The chief thrust of the narrative is to turn the attention of the readers to the cultural stories of the land. This is hoped to delete misappropriations and negative images circulated so far. Wright says, the white man's story is an imitation of the reality. "No, my boy listen to me first. It wasn't like that old fool told you. Never listen to him. He is only number one for a pack of lies. It was like what I am telling you because I saw it from the start to finish and he only know what I copied for him" (Wright Carpentaria479). The white man's history is short and discontinuous. To hide this flaw he supresses native stories, creates new stories of his own and circulates them using the government machinery. 
Old stories do not find active listeners and believers among the new generation. Will Phantom is described as knowing "a lot of half-told stories" (Wright, Carpentaria 479). They are misguided and misinformed. By the end of the novel, members of the community like Normal, Joseph and Will realise the importance of reviving these stories and transferring it to the next generation. It is at times like these memory plays a significant role.

Old stories circulating around the Pricklebush were full of the utmost intrigues concerning the world. Legends of the sea were told in instalments every time you walked in the door of some old person's house. Stories lasted months on end, and if you did not visit often, you would never know how the story ended. Will knew a lot of half-told stories... (479).

Hence memory gets transferred through transgenerational memory and everyday interactions. Certain mnemonic devices also induce memory. Cultural Memory includes among others two distinct features. Sites of memory and bearers of cultural memory. These are chiefly mnemonic in function.

\section{Sites of Memory}

One method to concretise memories is to turn to sites of memory. Jay Winter says, "Sites of memory are places where people affirm their faith that history has a meaning" (70). As events move further back into history, individuals and groups are forced to rely on sites that evoke memory of past events. They are points of reference and are static structures. But memories associated with them are in a state of flux. Jan Assmann refers to such places as sites of memory. He says they are "islands of time" (J. Assmann 129). They expand into more special arenas with the passage of time, acquiring meanings and significance according to the ideology of the society at the time. Myths are usually associated with sites of memory and hence assist generations in formation of personal or group identities. Will Phantom in 
Carpentariais wanted by the authorities on charges of a mine sabotage. During his wanderings to escape capture he discovers one such site of memory.

Will had climbed higher into the hills, until eventually, he came to a large rock cave. Inside, the walls were covered by ancestral paintings telling stories of human history, made and remade by ochre paints, as the forefathers whispered the charter of their land. Will acknowledged their presence, touched the walls in places to embrace the timelessness of his own being. He felt humbled, honoured to be in the home of birds, animals and clans people of time passed. (Wright, Carpentaria182)

Through the rock paintings the aboriginal forefathers" whisper "the charter of land" (182) meaning the methods of the land. Wright believes this power can revitalise generations of aboriginals. Temporal boundaries collapse into "timelessness" and the past, present and future collude in the caves. Will Phantom feels the presence of his guiding spirits as he touches the paintings. His rootlessness disappears and he is anchored to his land. The inner turmoil is pacified as aboriginal spirituality and heritage revitalises him. He now understands himself as an interactive member of the society and not an excluded one as he was made to believe.

\section{Bearers of Cultural memory}

J. Assmann believes that in each society certain members are designated as bearers of cultural memory. They are specialised agents who perform to ensure the memories of the race are carried forward. "With this we mean a) the institutional buttessing of communication, e.g., through formulization of the communicative situation in ceremony and b) the specialization of the bearers of cultural memory" (J. Assmann 131). Among the many figures of memory used in the novel the serpent is all compassing image. It helps to revive the 
aboriginal world that has disappeared behind colonisation and its accompanying modernity. The serpent is the store house for all their history.

The ancestral serpent, a creature larger than storm clouds, came down from the stars, laden with its own creative enormity. It moved graciously - if you had been watching with the eyes of a bird hovering in the sky far above the ground. Looking down at the serpent's wet body, glistering from the ancient sunlight, long before man was a creature who could contemplate the next moment in time. It came down those billions of years ago, to crawl on its heavy belly, all around the wet clay soils in the Gulf of Carpentaria. (Wright, Carpentaria 4).

The legend of the Rainbow Serpent that circulates in Australia describes how the plains of Australia became covered with rivers and mountains. The giant serpent in prehistoric times crawled around "the wet clay soils of the Gulf of Carpentaria" (4). It still exists in one of the rivers it created. The native people of Desperance can feel even today feel its presence.Wright says, "The river reminded me of the Rainbow Serpent that travels throughout the country and across our traditional lands" (Wright "Writing" 2) Hence by introducing the serpent Wright establishes the ancientness and authority of aboriginal world view.

Other bearers of include Normal who has three traces that makes him, a bearer of cultural memory. His workshop, a parrot and his knowledge of the ocean. In the same way Mozzie is also a bearer because he leads a convoy of zealots "along the spiritual travelling road of the great ancestor, whose journey continues to span the entire continent and is older than time itself' (Wright, Carpentaria 119). All these interactions among groups who believe in a "common image of their past" (J. Assmann 127) produce scope for circulation of communicative memory and cultural memory. 


\section{Conclusion}

In any form literature exhibits a particular culture, language or period in history. It cannot but reflect the life of the writer and the activities around him. This impels readers to think, imagine and form responses. All the above identified sites, rituals, mnemonic devices, bearers of cultural memory etc. are emplotted to foreground native history and memory. They are separated from their original contexts and combined and juxtaposed to expose the subjugation, trauma and degeneration suffered by the native societies. 


\section{Works Cited}

Assmann, Jan. "Collective Memory and Cultural Identity." Translated by John Czaplicka, New German Critique, no. 65, 1995, pp. 125-133. JSTOR, www.jstor.org/stable/488538.

Boer, Pim Den. “Loci Memoriae- Lieux de memoire.” Cultural Memory Studies: An International and Interdisciplinary Handbook. Edited byAstrid Erll and Ansgar Nunning, Walter de Gruyter, 2008, pp. 19-27.

Confino, Alon. "Memory and the History of Mentalities." Cultural Memory Studies: An International and Interdisciplinary Handbook. Edited byAstrid Erll and Ansgar Nunning, Walter de Gruyter, 2008, pp. 77-85.

Halbwachs, Maurice. On Collective Memory. Edited by Lewis A Coser. U of Chicago P, 1992.

Neumann, Bright. "The Literary Representation of Memory.” Cultural Memory Studies: An International and Interdisciplinary Handbook. Edited by Astrid Erll and Ansgar Nunning, Walter de Gruyter, 2008.

Winter, Jay. "Sites of Memory and Shadow of War." Cultural Memory Studies: An International and Interdisciplinary Handbook. Edited by Astrid Erll and Ansgar Nunning, Walter de Gruyter, 2008, pp. 61-77.

Wright, Alexis. Carpentaria. Navayana, 2015. ---. "On Writing Carpentaria.” Heat 13. Harper's Gold, 2007, pp. 79-95 http://logincms.uws.edu.au/_data/assets/pdf_file0011/385949. 